\title{
Correction to: A secure authentication technique for connecting different loT devices in the smart city infrastructure
}

\section{Rohit Sharma ${ }^{1}$ (D) $\cdot$ Rajeev Arya ${ }^{1}$}

Published online: 25 November 2021

(C) Springer Science+Business Media, LLC, part of Springer Nature 2021

\section{Correction to: Cluster Computing https://doi. org/10.1007/s10586-021-03444-8}

The original version of this article unfortunately contained a mistake. The citations of Chiou et al, Chen, Mohit et al, and Chen have been incorrectly cited with wrong reference numbers in the sections, tables and figures. The citations have now been corrected.

The original article has been corrected.

Publisher's Note Springer Nature remains neutral with regard to jurisdictional claims in published maps and institutional affiliations.

The original article can be found online at https:// doi.org/10.1007/s10586-021-03444-8.

Rohit Sharma

rohits.ph21.ec@nitp.ac.in

Rajeev Arya

rajeev.arya@nitp.ac.in

1 Wireless Sensor Networks Lab, Department of Electronics and Communication Engineering, National Institute of Technology Patna, Patna, Bihar 800005, India 